Acta vet. scand. $1970,11,156-180$.

From the Department of Obstetrics and Gynaecology and the Department of Clinical Biochemistry, Royal Veterinary College, Stockholm, Sweden.

\title{
A COMPARATIVE STUDY \\ ON THE CHEMICAL COMPOSITION OF PLASMA FROM THE CAUDA EPIDIDYMIDIS, SEMEN FRACTIONS, AND WHOLE SEMEN IN BOARS*)
}

\author{
By \\ Stig Einarsson, Bo Crabo and Lars Ekman
}

The boar has a very prolonged ejaculation and the semen is emitted in several fractions, of which the first has the highest proportion of fluid and the last is richest in gel (Mann 1964). The main fractions are the "pre-sperm fraction", the "spermrich fraction" and the "post-sperm fraction". The spermatozoa are delivered mainly in the "sperm-rich fraction". According to investigations by McKenzie et al. (1938) the "pre-sperm fraction" comprises 5-20\%, the "sperm-rich fraction" $30-50 \%$ and the "post-sperm fraction" 40-60\% of the total volume of ejaculate.

Several investigations have been carried out on the chemical composition of the cauda epididymal content in boars (Mann; Crabo 1965). The plasma of semen and semen fractions have also been studied (Nesmeianova 1936; McKenzie et al.; Glover \& Mann 1954; Mann). Comparative studies have been made of certain parameters of epididymal and ejaculated boar spermatozoa (Lasley \& Bogart 1944). No reports on systematic comparisons of the chemical composition of plasma from epididymis and ejaculate have been found in the literature.

*) The investigation was supported by grants from the Swedish Agricultural Research Council and Svensk Husdjursskötsel, Hållsta. 
The purpose of this investigation was to study the adverse environmental conditions experienced by the spermatozoa in the individual boar when they pass from the cauda epididymis into the semen during ejaculation. Chemical investigations were carried out on plasma from the cauda epididymis (collected post mortem), whole semen and semen fractions, with special regard to the sperm-containing fractions. The following is a report of certain preliminary results, obtained in the investigation.

\section{MATERIAL AND METHODS}

A total of 22 boars were used in this study. In some cases contents from the cauda epididymis only were obtained because of an inability to serve resulting from lameness. The boars ranged from 8 to 14 months of age and belonged to the Swedish Landrace or Swedish Yorkshire breeds. All boars were housed in individual pens in a common building. Feeding was conventional, based on ground grain with additional high protein concentrate (Suggex), plus minerals, trace elements and vitamins according to recommendations.

The sperm morphology of all boars was examined (Lagerlöf \& Carlquist 1961; Bane 1961) and only those which presented a normal semen picture were included in the investigation.

A dummy sow and artificial vagina were employed for semen collection. The semen was filtered through gauze following ejaculation and collected as whole semen and as semen fractions of $10 \mathrm{ml}$ in sampling tubes preheated to $37^{\circ} \mathrm{C}$. When whole semen collection was performed, filtration through gauze was done just after collection. Sperm motility and general sperm morphology of ejaculated semen were assessed by microscopical examination of a drop of semen on a slide with coverslip and maintained at $37^{\circ} \mathrm{C}$. Only ejaculates showing a normal picture were used for chemical analysis. The sperm concentration of ejaculated semen was estimated in a haemocytometer. The semen was taken to the laboratory immediately, the spermatozoa were separated from the seminal plasma by centrifugation for $15 \mathrm{~min}$. at 5,700 r.p.m., and the supernatant removed with glass pipettes. From each of four boars chemical analysis was performed in three whole and three fractionated ejaculates. From the other boars as a rule only one whole and one fractionated ejaculate were analysed. Testicles and epididymides were obtained at slaughter 
except once when they were secured at castration under local anaesthesia (Xylocain ${ }^{\circledR}$ ). The epididymal content was removed as soon as possible after slaughter and was centrifuged immediately. The method used for removal of material from the cauda epididymidis was as follows: small incisions were made in well-filled distended ducts, and with slight pressure on the cauda epididymidis the content was expelled (most often the epididymal content was under positive pressure) and was collected in preheated glass tubes (the glass tube was placed so that the epididymal contents flowed directly into it). The epididymal contents from the right and left cauda were analysed together. As a rule the sperm morphology was examined in the cauda epididymidis too.

Sperm concentration in the cauda epididymidis content was estimated by the spermatocrit method elaborated by Crabo (1965) with an "Autocrit" centrifuge (Clay-Adams INC).

Dry weight. In order to determine the amount of dry matter in the spermatozoa and in the seminal plasma, these were dried at $105^{\circ} \mathrm{C}$ until constant weight readings were obtained. Generally this required about $24 \mathrm{hrs}$. of heating.

Osmotic pressure in the seminal plasma was determined by an osmometer (model $31 \mathrm{LA}$, Advanced Instruments, INC).

Sodium and potassium were determined with an EEL flame photometer after dilution 1:500 and 1:50 with distilled water.

The chloride level was measured by titration according to the method described by Brun (1949) after dilution 1:5 with distilled water.

Inorganic phosphorus was determined colorimetrically according to Taussky et al. (1953) with a Beckman B spectrophotometer.

Calcium and magnesium. After dilution 1:25 and 1:200 with distilled water the levels of calcium and magnesium were measured with a Perkin-Elmer Atomic absorption spectrophotometer, model 202.

Protein. Total protein was determined after dilution with distilled water 1:25, according to Weichselbaum's method (1946). 
Paper electrophoresis was carried out using an LKB apparatus according to Valmet \& Svensson (1954) for 18 or $24 \mathrm{hrs}$. in TRIS buffer at $\mathrm{pH}$ 8.9. Amido black was used for staining the proteins and a Beckman-Spinco Analytrol for determining the colour intensities of the components.

Enzymes. GOT (Glutamic-oxaloacetic transaminase) and GPT (Glutamic-pyruvic transaminase) analyses were conducted according to the method described by Reitman \& Frankel (1957) using KABI's reagent. The alkaline phosphatase assay employed was King \& Armstrong's method (1934). Plasma from the cauda epididymidis and ejaculated semen were added to physiological saline in ratios of $1: 1,000$ and $1: 100$.

Statistical analyses. Standard statistical methods were used for all calculations (Bonnier \& Tedin 1940).

\section{RESULTS}

When collecting semen fractions, $10 \mathrm{ml}$ volumes of semen were collected in individual glass tubes. Varying numbers of tubes were thus filled during collection depending on the volume of the ejaculate. The contents of all tubes were not analysed in every case. Generally seven fractions were analysed and these were classed as follows:

T a b l e 1. Sperm concentration in the cauda epididymidis, semen fractions and whole semen in boars.

\begin{tabular}{|c|c|c|c|c|c|c|c|c|c|c|}
\hline & \multirow{2}{*}{\multicolumn{2}{|c|}{$\begin{array}{c}\text { Cauda } \\
\text { epididymidis }\end{array}$}} & \multicolumn{7}{|c|}{ Semen fraction number } & \multirow{2}{*}{$\begin{array}{l}\text { Whole } \\
\text { semen }\end{array}$} \\
\hline & & & I & II & III & IV & $\mathbf{v}$ & VI & VII & \\
\hline \multicolumn{11}{|c|}{$\begin{array}{l}\text { Sperm concentration } \\
\text { per } \mathrm{mm}^{3} \times 10^{3}\end{array}$} \\
\hline Mean & $=\overline{\mathrm{x}}$ & $3,210.0$ & 375.0 & $1,016.0$ & 528.0 & 125.0 & 0 & 0 & 0 & 228.9 \\
\hline $\begin{array}{l}\text { Standard } \\
\text { deviation }\end{array}$ & $=\mathbf{s}$ & 359.0 & 30.0 & 32.8 & 22.7 & 5.4 & & & & 80.9 \\
\hline $\begin{array}{l}\text { Number of } \\
\text { boars }\end{array}$ & $=\mathrm{n}$ & 21 & 6 & 12 & 12 & 12 & 9 & 12 & 12 & 11 \\
\hline
\end{tabular}


T a b l e 2. Osmotic pressure in the seminal plasma $(\mathrm{mOsm} / \mathrm{l})$, dry weight per cent of $\mathrm{sp}$ from the cauda epididymidis, semen fractions and whole semen in $b$

\begin{tabular}{|c|c|c|c|c|c|c|c|}
\hline \multirow[t]{2}{*}{ - } & & \multirow{2}{*}{$\begin{array}{l}\text { Cauda } \\
\text { epidi- } \\
\text { dymidis }\end{array}$} & \multicolumn{5}{|c|}{ Semen fraction number } \\
\hline & & & I & II & III & IV & $\mathbf{v}$ \\
\hline \multirow[t]{5}{*}{$\begin{array}{l}\text { Osmotic } \\
\text { pressure (mOsm/1) }\end{array}$} & $\begin{array}{l}\overline{\mathbf{x}} \\
\mathbf{s}\end{array}$ & $\begin{array}{r}334.5 \\
12.6\end{array}$ & $\begin{array}{r}298.2 \\
21.9\end{array}$ & $\begin{array}{r}301.2 \\
14.0\end{array}$ & $\begin{array}{r}302.3 \\
13.2\end{array}$ & $\begin{array}{r}303.9 \\
12.8\end{array}$ & $\begin{array}{r}305.6 \\
15.4\end{array}$ \\
\hline & $\mathbf{t}$ & & \multicolumn{2}{|c|}{0.35} & 20 & 30 & 8 \\
\hline & & & & \multicolumn{4}{|c|}{0.75} \\
\hline & & & & & & \multicolumn{2}{|c|}{1.73} \\
\hline & $\mathbf{n}$ & 21 & 6 & 12 & 12 & 12 & 9 \\
\hline \multirow[t]{3}{*}{$\begin{array}{l}\text { Dry weight } \\
\text { spermatozoa }(\%)\end{array}$} & $\begin{array}{l}\overline{\mathbf{x}} \\
\mathbf{s}\end{array}$ & $\begin{array}{r}25.47 \\
5.85\end{array}$ & $\begin{array}{l}21.18 \\
10.52\end{array}$ & $\begin{array}{r}19.91 \\
4.40\end{array}$ & $\begin{array}{r}16.83 \\
4.01\end{array}$ & $\begin{array}{r}18.11 \\
5.61\end{array}$ & \\
\hline & $\mathbf{t}$ & & \multicolumn{2}{|c|}{0.30} & 1.46 & .53 & \\
\hline & $\mathbf{n}$ & 9 & 4 & 8 & 8 & $\begin{array}{l}2.54 \\
8\end{array}$ & \\
\hline \multirow[t]{4}{*}{$\begin{array}{l}\text { Dry weight } \\
\text { plasma }(\%)\end{array}$} & $\begin{array}{l}\overline{\mathbf{x}} \\
\mathbf{s}\end{array}$ & $\begin{array}{l}4.56 \\
1.26\end{array}$ & $\begin{array}{l}2.20 \\
0.34\end{array}$ & $\begin{array}{l}3.84 \\
0.60\end{array}$ & $\begin{array}{l}4.05 \\
1.22\end{array}$ & $\begin{array}{l}4.51 \\
0.82\end{array}$ & $\begin{array}{l}3.84 \\
1.49\end{array}$ \\
\hline & $\mathbf{t}$ & & \multicolumn{2}{|r|}{$5.01^{\star \star \star}$} & 0.44 & .88 & .06 \\
\hline & & & \multicolumn{5}{|c|}{0.10} \\
\hline & $\mathbf{n}$ & 8 & 4 & 8 & 8 & $\begin{array}{l}0.91 \\
8\end{array}$ & 5 \\
\hline
\end{tabular}


I. The fraction immediately before the sperm-richest fraction.

II. The sperm-richest fraction.

III. The fraction immediately after the sperm-richest fraction.

IV. The last fraction with spermatozoa.

V. The first sperm-free fraction.

VI. The middle sperm-free fraction.

VII. The last sperm-free fraction.

Sperm concentration. As is evident from Table 1, the mean sperm concentration in the cauda epididymidis was 3.2 mill. sperm $/ \mathrm{mm}^{3}$. Sperm concentration in the sperm-richest fraction (II) was approximately $1 \mathrm{mill}$. sperm $/ \mathrm{mm}^{3}$ compared with 0.23 mill. sperm $/ \mathrm{mm}^{3}$ in whole semen.

Dry weight. The dry weight was determined both for spermatozoa and seminal plasma as per cent dry matter. As is evident from Table 2 the dry weight of spermatozoa was highest in the cauda epididymidis (25.47\%), demonstrating a tendency to decrease gradually in fractions I-IV, and was lowest in whole semen $(15.29 \%)$. Statistical comparison disclosed a highly significant difference between spermatozoa from the cauda epididymidis and from whole semen, as well as a significant or almost significant difference between spermatozoa from the cauda epididymidis and semen fractions II, III and IV (Table 2a). The per cent dry weight in plasma fell by half between the cauda epididymidis and semen fraction I (Table 2). Thereafter it rose in the sperm-containing fractions II, III and IV, and then re-

T a b l e 2a. Significance test between the cauda epididymidis, semen fractions I-IV, and whole semen for plasma osmotic pressure, spermatozoa dry weight and plasma dry weight.

\begin{tabular}{llllll}
\hline & \multicolumn{4}{c}{ Semen fractions } & Whole \\
\cline { 2 - 5 } & I & II & III & IV & semen \\
\hline $\begin{array}{l}\text { Osmotic pressure } \\
\begin{array}{l}\text { Dry weight, } \\
\text { spermatozoa }\end{array}\end{array}$ & $5.24^{\star \star \star}$ & $7.02^{\star \star \star}$ & $6.94^{\star \star \star}$ & $6.67^{\star \star \star}$ & $5.06^{\star \star *}$ \\
$\begin{array}{l}\text { Dry weight, } \\
\text { plasma }\end{array}$ & 0.95 & $2.19^{\star}$ & $3.50^{\star \star}$ & $2.64^{\star}$ & $4.52^{\star \star *}$ \\
\hline
\end{tabular}


T a b le 3. Concentration of sodium, potassium and chloride (meq/l) in plasma from semen fractions and whole semen.

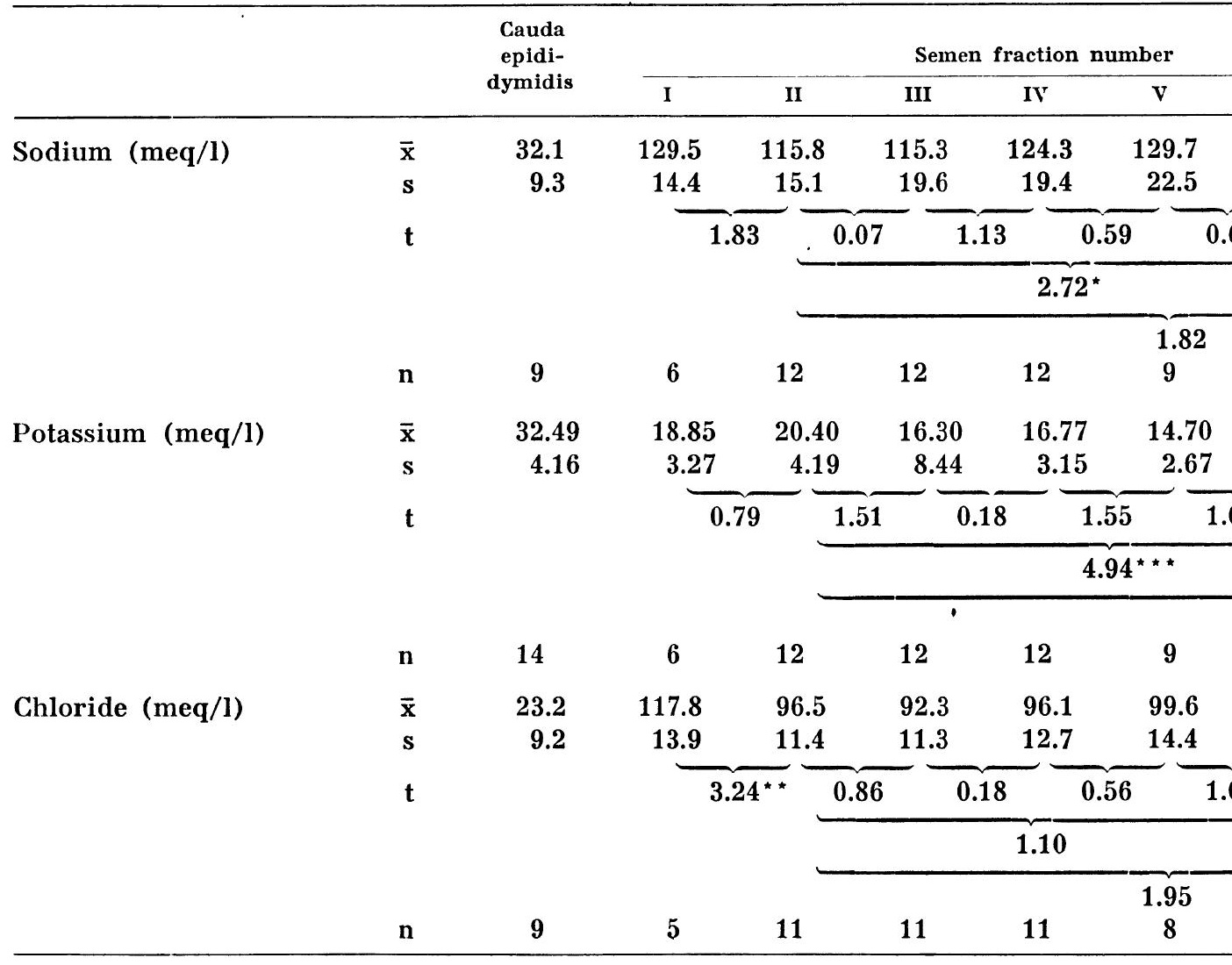


mained at the same level in the sperm-free fractions. The per cent dry weight of the plasma was significantly lower in fraction 1 than in the cauda epididymidis and fraction II (Tables 2 and 2a). The gradual rise between fractions II, III and IV was not statistically significant.

Osmotic pressure. The osmotic pressure was without exception higher in plasma from the cauda epididymidis than in plasma from whole semen and semen fractions I-VII (Table 2).

The difference in osmotic pressure between the cauda epididymidis and whole semen and between the cauda epididymidis and all the sperm-containing fractions (I, II, III and IV) was highly significant (Table $2 a$ ).

\section{Electrolytes}

Sodium. The sodium concentration was lowest in plasma from the cauda epididymidis (32.1 meq/l). From a comparatively high value in fraction $I$, it fell in the sperm-rich fractions II and III after which there was a gradual increase through the fractions (Table 3 ). The difference between fractions II and VI was almost significant. Statistical comparison between the cauda epididymidis and both whole semen and fractions I-IV revealed highly significant differences (Table $3 \mathrm{a}$ ).

T a ble 3a. Significance test between cauda epididymidis and the sperm-containing fractions I-IV and whole semen for plasma sodium, potassium and chloride.

\begin{tabular}{lrrrrr}
\hline & \multicolumn{4}{c}{ Semen fractions } & \multicolumn{1}{c}{$\begin{array}{l}\text { Whole } \\
\text { semen }\end{array}$} \\
\cline { 2 - 5 } Sodium & \multicolumn{1}{c}{ I } & \multicolumn{1}{c}{ II } & \multicolumn{1}{c}{ III } & IV & \\
\hline Potassium & $15.94^{\star \star \star}$ & $14.59^{\star \star \star}$ & $11.71^{\star \star \star}$ & $13.10^{\star \star \star}$ & $23.45^{\star \star \star}$ \\
Chloride & $7.10^{\star \star \star}$ & $7.36^{\star \star \star}$ & $6.35^{\star \star \star}$ & $10.71^{\star \star \star}$ & $9^{\star 88^{\star \star \star}}$ \\
\hline
\end{tabular}

Potassium. The highest value occurred in the cauda epididymidis $(32.49 \mathrm{meq} / \mathrm{l})$ and the lowest in the sperm-free fractions VI and VII (13.49 and $13.33 \mathrm{meq} / \mathrm{l}$ respectively) (Table 3 ). The potassium concentration showed a gradual decrease from fraction II to fraction VII $(20.40-13.33 \mathrm{meq} / \mathrm{l})$. Statistical comparison revealed a highly significant difference between plasma from the cauda epididymidis and from whole semen and between cauda epididymidis and the sperm-containing fractions (Table 
3a). The difference between fractions II and VI was highly significant (Table 3), and between fraction II and whole semen the difference was significant.

Chloride. The variation of chloride concentration in the plasma was in general similar to that of sodium concentration (Table 3 ). The concentration was lowest in the cauda epididymidis $(23.2 \mathrm{meq} / \mathrm{l})$. In the same fractions there was first a gradual decrease (fractions I-III) and thereafter a gradual increase to fraction VI whence the value was constant. The mean value of the concentration demonstrated a highly significant difference between the cauda epididymidis and whole semen and between the cauda epididymidis and fractions I, II, III and IV (Table 3a). Furthermore there was a significant difference between fractions I and II (Table 3). Statistical comparison between individual boars showed significant differences of varying

T a b l e $3 \mathrm{~b}$. Statistical comparison of the chloride concentration in plasma of individual boars for whole semen and semen fractions.

\begin{tabular}{|c|c|c|c|c|c|c|c|c|c|}
\hline \multirow[b]{2}{*}{ Boar } & \multirow[b]{2}{*}{$\begin{array}{l}\text { Ejaculate } \\
\text { number }\end{array}$} & \multicolumn{7}{|c|}{ Semen fraction number } & \multirow{2}{*}{$\begin{array}{l}\text { Whole } \\
\text { semen }\end{array}$} \\
\hline & & I & II & III & IV & $\mathbf{v}$ & VI & VII & \\
\hline \multirow[t]{4}{*}{1} & 1 & - & 90 & 73 & 76 & $8 \dot{4}$ & 83 & 84 & 91 \\
\hline & 2 & - & 97 & 75 & 78 & 80 & 83 & 81 & 93 \\
\hline & 3 & - & 92 & 86 & 86 & 89 & 89 & 90 & 90 \\
\hline & mean & - & 93.0 & 78.0 & 80.0 & 84.3 & 85.0 & 85.0 & 91.3 \\
\hline \multirow[t]{4}{*}{2} & 1 & - & 103 & 93 & 103 & 104 & 120 & 120 & 113 \\
\hline & 2 & - & 101 & 101 & 104 & 112 & 114 & - & 108 \\
\hline & 3 & - & 100 & 91 & 94 & 100 & 109 & 109 & 100 \\
\hline & mean & - & 103.3 & 95.0 & 100.3 & 105.3 & 114.3 & 114.5 & 107.0 \\
\hline \multirow[t]{4}{*}{3} & 1 & - & 112 & 97 & 102 & 119 & - & 118 & 98 \\
\hline & 2 & 135 & 97 & 88 & 94 & 96 & 111 & 115 & 93 \\
\hline & $\overline{3}$ & 140 & 129 & 117 & 110 & 125 & 121 & 119 & 112 \\
\hline & mean & 137.5 & 112.7 & 100.7 & 102.0 & 113.3 & 116.0 & 117.3 & 101.0 \\
\hline \multirow[t]{4}{*}{4} & 1 & - & 109 & 91 & 93 & 92 & 96 & 99 & 111 \\
\hline & 2 & 108 & 84 & 84 & 83 & 一 & 86 & 86 & 111 \\
\hline & 3 & - & 106 & 95 & 95 & 98 & 96 & 100 & 110 \\
\hline & mean & 108.0 & 90.0 & 99.7 & 90.3 & 95.0 & 92.7 & 95.0 & $110 . \bar{i}$ \\
\hline \multicolumn{3}{|c|}{ Variance ratioa) } & 1.75 & 3.40 & $7.59^{\star \star}$ & $5.44^{*}$ & $25.03^{*}$ & * 20.33 & 5.99 \\
\hline
\end{tabular}

a) Variance ratio $=\frac{\text { mean square between samples }}{\text { mean square within samples }}$ 
T a b l e 4. Inorganic phosphorus (mg/100 ml), calcium and magnesium levels (meq/l) epididymidis, semen fractions and whole semen in boars.

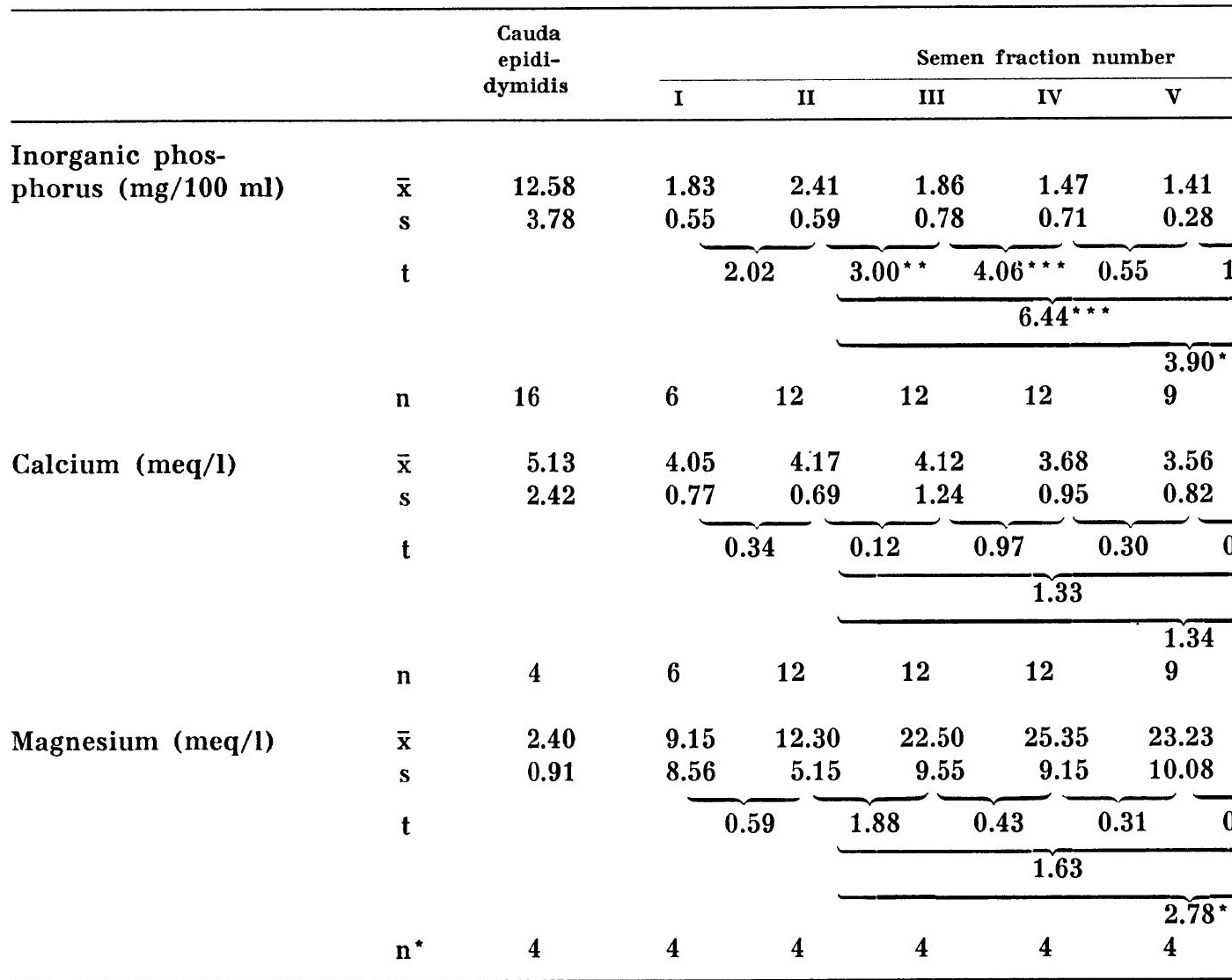

* Three whole semen ejaculates and three ejaculates in semen fractions collected from ea 
degrees for fractions IV, V, VI, and VII and for whole semen (Table $3 \mathrm{~b}$ ).

Inorganic phosphorus. The content of inorganic phosphorus was markedly higher in plasma from the cauda epididymidis than in plasma from whole semen (Table 4). In the semen fractions there was a gradual decrease from fraction II to fraction VII, and this decrease was statistically significant between fractions II and III and highly significant between III and IV. Statistical comparison between the cauda epididymidis and whole semen as well as between the cauda epididymidis and the spermcontaining fractions I-IV revealed highly significant differences (Table 4a).

T a b l e 4 a. Significance test between cauda epididymidis, the semen fractions I-IV and whole semen regarding the different levels of inorganic phosphorus, calcium and magnesium.

\begin{tabular}{|c|c|c|c|c|c|}
\hline & \multicolumn{4}{|c|}{ Semen fractions } & \multirow{2}{*}{$\begin{array}{l}\text { Whole } \\
\text { semen }\end{array}$} \\
\hline & I & II & III & IV & \\
\hline Inorganic & $683^{\star \star \star \star ~}$ & $919^{\star \star \star \star}$ & $976^{\star \star \star \star}$ & $1011^{\star \star \star \star}$ & a $55 \star \star \star \star$ \\
\hline Calcium & 1.05 & 1.30 & 1.12 & 1.79 & 0.60 \\
\hline Magnesium & 1.79 & $3.78^{\star \star}$ & $4.19^{\star \star}$ & $4.98^{\star \star}$ & $6.73^{\star \star \star}$ \\
\hline
\end{tabular}

Calcium. As is evident from Table 4 the calcium concentration was highest in the cauda epididymidis $(5.13 \mathrm{meq} / \mathrm{l})$. In the semen fractions there was a tendency towards higher concentrations in those containing spermatozoa. Statistical comparison revealed no significant differences, however.

Magnesium. The plasma from the cauda epididymidis contained a low concentration of magnesium $(2.40 \mathrm{meq} / \mathrm{l})$. In the semen fractions the magnesium concentration rose gradually from fractions $I$ to $I V$, whence the concentration remained at approximately the same level in the sperm-free fractions. Statistical comparison disclosed highly significant differences between the cauda epididymidis and whole semen and between the cauda epididymidis and fractions II, III and IV (Table $4 \mathrm{a}$ ). Statistically there were differences of varying degrees between individual boars as regards fractions II, III, IV, V, VI and VII (Table $4 \mathrm{~b}$ ). 
T a b l e 4 b. Statistical comparison of the magnesium concentration of individual boars for whole semen and semen fractions.

\begin{tabular}{|c|c|c|c|c|c|c|c|c|c|}
\hline \multirow[b]{2}{*}{ Boar } & \multirow[b]{2}{*}{$\begin{array}{c}\text { Ejaculate } \\
\text { number }\end{array}$} & \multicolumn{6}{|c|}{ Semen fraction number } & \multirow[b]{2}{*}{ VII } & \multirow{2}{*}{$\begin{array}{l}\text { Whole } \\
\text { semen }\end{array}$} \\
\hline & & $\mathbf{I}$ & II & III & IV & $\mathbf{v}$ & VI & & \\
\hline \multirow[t]{4}{*}{1} & 1 & - & 25.0 & 42.0 & 44.0 & 43.0 & 43.0 & 44.0 & $\mathbf{3 7 . 0}$ \\
\hline & 2 & - & 14.0 & 37.0 & 40.0 & 39.0 & 38.0 & 40.0 & 32.0 \\
\hline & 3 & - & 19.0 & 30.0 & 31.0 & 30.0 & 30.0 & 33.0 & 18.0 \\
\hline & mean & - & 19.33 & 36.33 & 38.33 & 37.33 & 37.00 & 39.00 & 29.00 \\
\hline \multirow[t]{4}{*}{2} & 1 & - & 12.0 & 22.0 & 22.0 & 22.0 & 13.1 & 15.0 & 23.0 \\
\hline & 2 & - & 14.4 & 18.4 & 18.4 & 16.8 & 14.4 & - & 12.8 \\
\hline & 3 & - & 12.0 & 24.2 & 24.2 & 22.4 & 18.4 & 13.6 & 15.2 \\
\hline & mean & - & 12.80 & 21.53 & 21.53 & 20.40 & 15.27 & 14.30 & 17.00 \\
\hline \multirow[t]{4}{*}{3} & 1 & - & 4.8 & 15.2 & 17.2 & 8.0 & - & 6.4 & 23.0 \\
\hline & 2 & 4.0 & 12.8 & 18.4 & 19.2 & 19.2 & 13.6 & 11.6 & 24.0 \\
\hline & 3 & 2,0 & 4.8 & 14.2 & 14.8 & 13.6 & 12.4 & 15.6 & 11.2 \\
\hline & mean & 3.00 & 7.47 & 15.93 & 17.07 & 13.60 & 13.00 & 11.20 & 19.40 \\
\hline \multirow[t]{4}{*}{4} & 1 & - & 8.0 & 20.0 & 29.6 & 25.6 & 23.2 & 21.6 & 25.2 \\
\hline & 2 & 15.2 & 14.4 & 16.8 & 26.4 & - & 27.2 & 26.4 & 18.0 \\
\hline & 3 & - & 6.4 & 12.0 & 17.6 & 17.6 & 18.4 & 16.0 & 42.5 \\
\hline & mean & 15.20 & 9.60 & 16.27 & 24.53 & 21.60 & 22.93 & 21.33 & 28.57 \\
\hline \multicolumn{2}{|c|}{ Variance ratioa) } & & $4.50^{\star}$ & $12.74^{\star \star}$ & $10.48^{\star \star}$ & $10.40^{\star \star}$ & $15.98^{\star *}$ & $19.53^{\star \star}$ & 1.38 \\
\hline
\end{tabular}

a) Variance ratio $=\frac{\text { mean square between samples }}{\text { mean square within samples }}$

\section{Protein}

Total protein. The plasma protein concentrations are summarized in Table 5. The concentration was $2.47 \mathrm{~g} / 100 \mathrm{ml}$ in plasma from the cauda epididymidis and $2.98 \mathrm{~g} / 100 \mathrm{ml}$ in plasma from whole semen. In plasma from semen fractions the protein concentration gradually rose from fraction I to fraction IV (1.43$3.13 \mathrm{~g} / 100 \mathrm{ml}$ ) fell to $2.71 \mathrm{~g} / 100 \mathrm{ml}$ in the first sperm-free fraction ( $\mathrm{V}$ ) and then stayed at the same level in the remaining fractions. The mean protein concentration revealed a statistically significant difference between the cauda epididymidis and fraction I (Table 5a). An almost significant difference was revealed when compairing fractions III, IV, and V between boars and a significant difference was evident for fractions VI and VII (Table $5 \mathrm{~b}$ ). 
T a b l e 5. Plasma protein concentration $(\mathrm{g} / 100 \mathrm{ml})$ and paper electrophoretic compone plasma from the cauda epididymidis, semen fractions and whole se

\begin{tabular}{|c|c|c|c|c|c|c|c|}
\hline & & \multirow{2}{*}{$\begin{array}{l}\text { Cauda } \\
\text { epidi- } \\
\text { dymidis }\end{array}$} & \multicolumn{5}{|c|}{ Semen fraction number } \\
\hline & & & I & II & III & IV & $\mathbf{v}$ \\
\hline \multirow{5}{*}{$\begin{array}{l}\text { Total protein } \\
(\mathrm{g} / 100 \mathrm{ml})\end{array}$} & $\overline{\mathbf{x}}$ & 2.47 & 1.43 & 1.88 & 2.67 & 3.13 & 2.71 \\
\hline & $\mathbf{s}$ & 0.56 & 1.10 & 1.05 & 1.27 & 1.13 & 1.28 \\
\hline & $\mathbf{t}$ & & & & & & 0 \\
\hline & & & & & & 1.70 & \\
\hline & $\mathbf{n}$ & 19 & 6 & 12 & 11 & 12 & $\begin{array}{l}2.50^{\star} \\
9\end{array}$ \\
\hline \multicolumn{8}{|c|}{$\begin{array}{l}\text { Electrophoretic } \\
\text { fraction }(\mathrm{g} / 100 \mathrm{ml})\end{array}$} \\
\hline \multirow[t]{3}{*}{1} & $\overline{\mathbf{x}}$ & 0.09 & 0 & 0 & 0 & $\mathbf{0}$ & $\mathbf{0}$ \\
\hline & $\mathbf{s}$ & 0.10 & & & & & \\
\hline & $\mathbf{n}$ & 17. & 5 & 11 & 11 & 11 & 8 \\
\hline \multirow[t]{3}{*}{2} & $\overline{\mathbf{x}}$ & 0.43 & 0.08 & 0.11 & 0.03 & $\mathbf{0}$ & $\mathbf{0}$ \\
\hline & $\mathbf{s}$ & 0.23 & 0.08 & 0.11 & 0.05 & & \\
\hline & $\mathbf{n}$ & 17 & 5 & 11 & 11 & 11 & 8 \\
\hline \multirow[t]{3}{*}{3} & $\overline{\mathbf{x}}$ & 1.45 & 0.28 & 0.55 & 0.52 & 0.38 & 0.28 \\
\hline & $\mathbf{s}$ & 0.44 & 0.08 & 0.19 & 0.29 & 0.19 & 0.16 \\
\hline & $\mathbf{n}$ & 17 & 5 & 11 & 11 & 11 & 8 \\
\hline \multirow[t]{3}{*}{4} & $\overline{\mathbf{x}}$ & 0.49 & 0.42 & 0.71 & 1.13 & 1.30 & 1.15 \\
\hline & $\mathbf{s}$ & 0.29 & 0.29 & 0.35 & 0.39 & 0.48 & 0.53 \\
\hline & $\mathbf{n}$ & 17 & 5 & 11 & 11 & 11 & 8 \\
\hline \multirow[t]{3}{*}{5} & $\overline{\mathbf{x}}$ & 0 & 0.28 & 0.34 & 0.94 & 1.25 & 1.18 \\
\hline & $\mathbf{s}$ & 0 & 0.28 & 0.19 & 0.48 & 0.47 & 0.44 \\
\hline & $\mathbf{n}$ & 17 & 5 & 11 & 11 & 11 & 8 \\
\hline
\end{tabular}


T a b l e 5a. Significance test between the cauda epididymidis, semen fractions I-IV and whole semen for the plasma protein level.

\begin{tabular}{lccccc}
\hline & \multicolumn{4}{c}{ Semen fractions } & \multirow{2}{*}{$\begin{array}{l}\text { Whole } \\
\text { semen }\end{array}$} \\
\cline { 2 - 6 } & I & II & III & IV & \\
\hline Total protein & $3.12^{\star \star}$ & $2.05^{\star}$ & 0.60 & 2.17 & 1.18 \\
\hline
\end{tabular}

Paper electrophoresis. The results of paper electrophoresis are summarized in Table 5. The number of distinct components differs in plasma from the cauda epididymidis and ejaculated semen. Usually there are four distinct zones in plasma from the cauda epididymidis (sometimes only three could be distinguished, independent of whether the separation time was 18 or $24 \mathrm{hrs}$.) and three in plasma from whole semen. The electrophoretic components are numbered 1, 2, 3, 4 and 5 from the cathode to the anode (see diagram).

$\mathrm{T}$ a b l e $5 \mathrm{~b}$. Variation of the plasma protein content of whole semen and semen fractions in individual boars.

\begin{tabular}{|c|c|c|c|c|c|c|c|c|c|}
\hline \multirow[b]{2}{*}{ Boar } & \multirow[b]{2}{*}{$\begin{array}{l}\text { Ejaculate } \\
\text { number }\end{array}$} & \multicolumn{7}{|c|}{ Semen fraction number } & \multirow{2}{*}{$\begin{array}{l}\text { Whole } \\
\text { semen }\end{array}$} \\
\hline & & I & II & III & IV & $\mathbf{v}$ & VI & VII & \\
\hline \multirow[t]{4}{*}{1} & 1 & - & 3.0 & 5.2 & 5.2 & 4.9 & 4.9 & 5.2 & 3.8 \\
\hline & 2 & - & 2.0 & 4.4 & 4.8 & 4.6 & 4.4 & 4.7 & 3.2 \\
\hline & 3 & - & 2.3 & 3.2 & 3.3 & 3.2 & 3.2 & 3.6 & 3.5 \\
\hline & mean & - & 2.43 & 4.27 & 4.43 & 4.23 & 4.17 & 4.50 & 3.50 \\
\hline \multirow[t]{4}{*}{2} & 1 & - & 1.8 & 2.9 & 2.5 & 2.6 & 1.3 & 1.7 & 3.2 \\
\hline & 2 & - & 2.4 & 2.6 & 2.6 & 2.3 & 1.7 & - & 1.7 \\
\hline & 3 & - & 1.8 & 2.8 & 2.6 & 2.3 & 1.7 & 1.4 & 2.0 \\
\hline & mean & - & 2.00 & 2.77 & 2.57 & 2.40 & 1.57 & 1.55 & 2.30 \\
\hline \multirow[t]{4}{*}{3} & 1 & - & 1.0 & 2.4 & 2.7 & 1.0 & - & 1.8 & 3.2 \\
\hline & 2 & 0.5 & 1.9 & 3.6 & 3.5 & 3.2 & 1.6 & 1.1 & 3.2 \\
\hline & 3 & 0.4 & 0.7 & 1.8 & 2.1 & 1.9 & 1.6 & 1.8 & 1.7 \\
\hline & mean & 0.45 & 1.20 & 2.60 & 2.77 & 2.03 & 1.60 & 1.57 & 2.80 \\
\hline \multirow[t]{4}{*}{4} & 1 & - & 1.3 & 2.7 & 2.5 & 2.9 & 2.4 & 2.2 & 2.4 \\
\hline & 2 & 1.8 & 2.1 & 2.2 & 3.1 & - & 2.8 & 3.1 & 3.0 \\
\hline & 3 & - & 1.2 & 1.6 & 2.1 & 2.1 & 2.1 & 1.8 & 1.7 \\
\hline & mean & 1.80 & 1.53 & 2.17 & 2.57 & 2.50 & 2.43 & 2.37 & 2.37 \\
\hline \multicolumn{2}{|c|}{ Variance ratioa) } & & 3.43 & $4.59^{\star}$ & $5.60^{\star}$ & $4.48^{\star}$ & $15.60^{\star \star}$ & $14.72^{\star *}$ & 1.76 \\
\hline
\end{tabular}

mean square between samples

a) Variance ratio $=\frac{}{\text { mean square within samples }}$ 
Anode

Application point

$\begin{array}{lllll}5 & 4 & 3 & 2 & 1\end{array}$

Cathode

If this nomenclature is used, the electrophoretic components in the cauda epididymal plasma will be numbered 1, 2, 3 and 4 and in whole seminal plasma 3,4 and 5 . In whole semen fractions electrophoretic component 2 could only be distinguished in the fractions I, II and III. Components 3,4 and 5 could, however, be seen in all semen fractions. Electrophoretic component 3 was very distinct in the cauda epididymidis and comparatively more marked in the sperm-containing fractions than in the sperm-free fractions (Table 5). Electrophoretic components 4 and 5 were largest in the semen fraction IV and smallest in the sperm-containing fractions I, II and III.

\section{Enzymes}

GOT. The cauda epididymal plasma contained a very high amount of GOT per ml compared with plasma of whole semen (Table 6). Thus the GOT activity was 99.1 i.u. in cauda epididymal plasma and 11.1 i.u. in whole seminal plasma. The amount of GOT was higher in the sperm-containing fractions than in the sperm-free fractions. Statistical comparison revealed highly significant differences between the cauda epididymidis and whole semen and between the cauda epididymidis and fractions I, II, III and IV (Table 6a). Moreover there was a significant difference between fractions II and VI.

GPT. As is evident from Table 6 the GPT activity in seminal plasma is somewhat higher in the sperm-free fractions than in the sperm-containing fractions. No real difference was found between the cauda epididymidis and the ejaculate. Statistical analysis showed a highly significant difference between fractions II and VI.

Alkaline phosphatase. There was high alkaline phosphatase activity in plasma from the cauda epididymidis $(31,463 \mathrm{i} . \mathrm{u} . / \mathrm{ml})$. In semen fractions the activity was markedly more intensive in the sperm-containing fractions than in the sperm-free fractions. Thus the activity gradually decreased from 7,096 in fraction II to 363 i.u./ml in fraction VII (Table 6). Statistical analysis revealed a highly significant difference between the cauda epidi- 
T a ble 6. The amount of GOT (i.u./ml), GPT (i.u./ml), and alkaline phosphatase (i.u. cauda epididymidis, semen fractions, and whole semen.

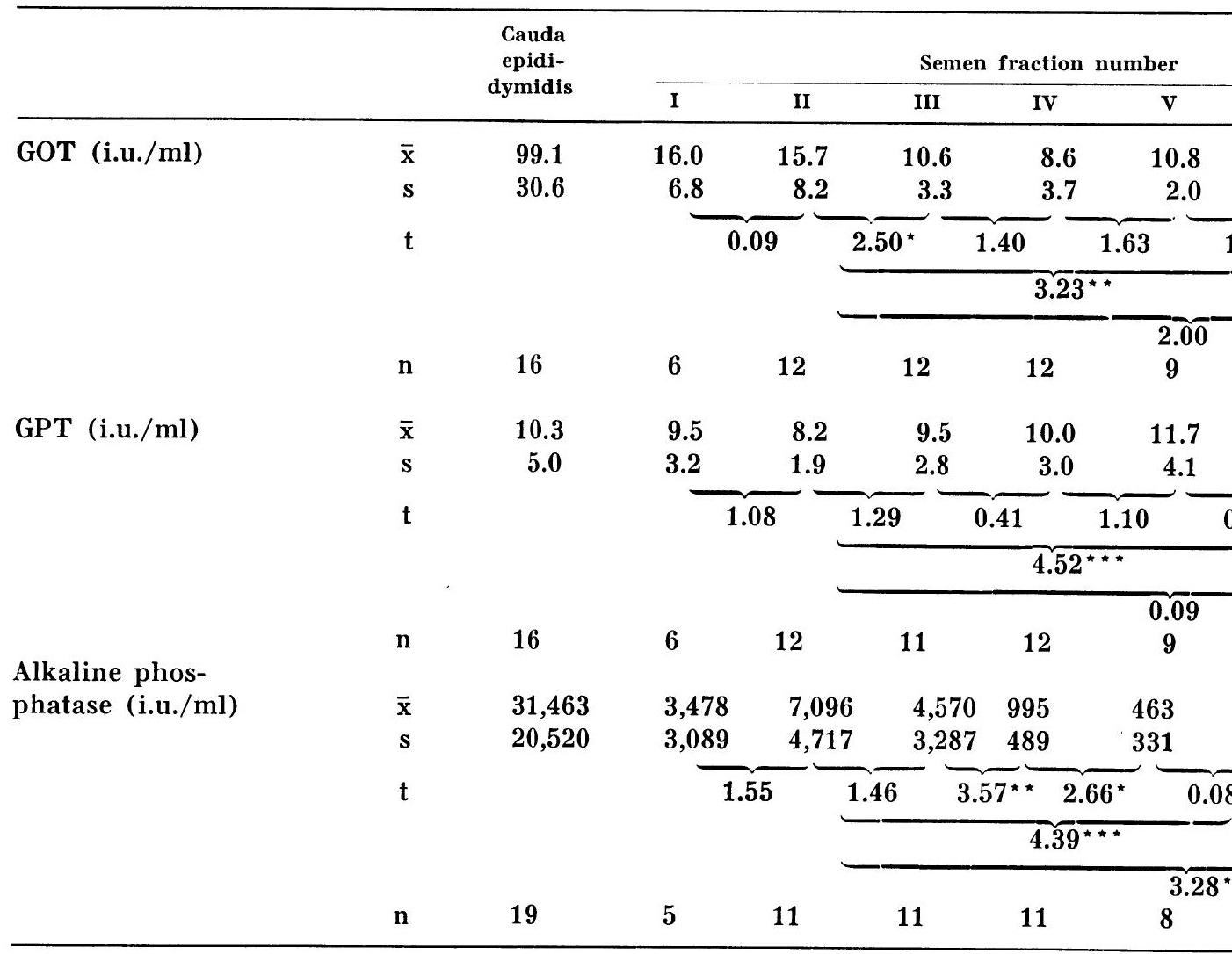


Table 6a. Significance test in plasma between the cauda epididymidis, the sperm-containing fractions I-IV, and whole semen for the GOT, GPT, and alkaline phosphatase levels.

\begin{tabular}{llllll}
\hline & \multicolumn{4}{c}{ Semen fractions } & \multirow{2}{*}{$\begin{array}{l}\text { Whole } \\
\text { semen }\end{array}$} \\
\cline { 2 - 5 } & \multicolumn{1}{c}{ I } & II & III & IV & \\
\hline GOT & $6.49^{\star \star \star}$ & $9.25^{\star \star \star}$ & $9.89^{\star \star \star}$ & $10.12^{\star \star \star}$ & $9.39^{\star \star \star}$ \\
GPT & 0.36 & 1.38 & 0.48 & 0.19 & 1.30 \\
Alkaline phosphatase & $2.99^{\star \star}$ & $3.85^{\star \star \star}$ & $4.28^{\star \star \star}$ & $4.88^{\star \star \star}$ & $4.69^{\star \star \star}$ \\
\hline
\end{tabular}

dymidis and whole semen, and significant differences between the cauda epididymidis and fractions II, III, and IV (Table 6a). Moreover there was a highly significant difference between fractions II and VI and a significant difference between fraction II and whole semen (Table 6).

\section{DISCUSSION}

The sperm concentration in the cauda epididymidis (Table 1) corresponds well with earlier investigations (Crabo 1965). The sperm concentration was high in the sperm-richest fraction (II) where the mean value was approximately $1 \mathrm{mill}$. sperm $/ \mathrm{mm}^{3}$. Thus the dilution of the spermatozoa was $1: 3$ between the cauda epididymidis and semen fraction II compared with a dilution of 1:14 between the cauda epididymidis and whole semen (Table 1). It is important to note this difference in dilution, especially as it is usually the sperm-rich part of the ejarulate which is used in artifical insemination of swine. The statistical analyses are therefore limited mainly to comparisons of the chemical composition of plasma from the cauda epididymidis, the sperm-rich fraction (II), and whole semen.

The osmotic pressure was higher in plasma from the cauda epididymidis, collected post mortem, compared with plasma from the ejaculate (Table 2). The same phenomenon was reported in the bull by Salisbury et al. (1948), Rothschild \& Barnes (1954) and Salisbury \& Cragle (1956). The osmotic pressure in plasma from the cauda epididymidis, collected repeatedly from a patent established fistula, with the vas deferens on the other side ligated, was significantly higher $(P<0.001)$ than the osmotic pressure in plasma from the accessory and urethral glands collected from the penis in the same boar (Einarsson 1969). Thus the spermatozoa are exposed to fluids with lower osmotic pressures 
when they pass into the seminal plasma during the ejaculation. The dry weight of the spermatozoa should also be considered here. As is evident from Table 2, the spermatozoal dry weight is higher in the cauda epididymidis than in the ejaculate. It was found that the difference was most pronounced between spermatozoa from the cauda epididymidis and whole semen, the dry weight being $25.47 \%$ and $15.29 \%$ respectively. The lower dry weight could possibly indicate a leakage of intracellular material from the spermatozoa when exposed to the accessory gland secretions which possess a lower osmotic pressure. On the other hand Drevius \& Eriksson (1966) found that spermatozoa, suspended in hypotonic salt solutions, take in water and swell, this being associated with a fall in the cellular specific gravity. Salisbury \& Cragle found a lower osmotic pressure in seminal plasma than in epididymal plasma and suggest that this causes water to enter the cells which may initiate the chemical reactions essential for motility. Thus the decrease in dry weight of spermatozoa from the cauda epididymidis, when diluted with the accessory gland secretions which have a lower osmotic pressure, is probably explained by an uptake of water. This explanation is in agreement with Gledhill's findings (1966), that there is no difference in the total dry matter content between spermatozoa in the cauda epididymidis and spermatozoa in the ejaculate of bulls. Previous investigators found that spermatozoa had a lower dry weight in the cauda epididymidis than in the ejaculate (Lindahl \& Thunqvist 1965; Pickett et al. 1967).

Comparative studies of the mineral content in plasma from the cauda epididymidis and the ejaculate revealed a markedly higher concentration of sodium, chloride and magnesium in plasma from the ejaculate (Tables 3 and 4 ). The reverse was true for potassium and inorganic phosphorus. There was only a slight difference in calcium concentration between plasma from the cauda epididymidis and the ejaculate (Tablc 4). The results agree well with earlier investigations (Mann 1964; Crabo). The sperm-containing fractions contained less sodium, chloride and magnesium than the sperm-free fractions. On the other hand the concentration of potassium and inorganic phosphorus was higher in the sperm-containing fractions than in the sperm-free fractions (Tables 3 and 4). A relationship beween sperm concentration and the amount of potassium, inorganic phosphorus and magnesium is possible and depends on the addition of cauda 
epididymal plasma to the sperm-containing fractions during ejaculation.

Nesmeianova (1936) reported in contrast to McKenzie et al. (1938) that the sperm-rich fraction contained the largest amount of minerals. It is interesting to note the high concentration of magnesium in the semen plasma compared with that in the cauda epididymidis (Table 4). Earlier investigations (Mann) have demonstrated relatively low magnesium concentration compared with that of calcium, which should give a magnesium-calcium ratio of approximately 2 for whole seminal plasma. In the present investigation the magnesium-calcium ratio was found to be much higher. Thus there was a ratio of approximately 10 for whole seminal plasma, 5 for semen fraction II and as low as 0.5 for plasma from the cauda epididymidis.

Statistical analysis of mean values for chloride and magnesium revealed significant differences between individual boars in the majority of semen fractions (Tables $3 \mathrm{~b}$ and $4 \mathrm{~b}$ ).

The concentration of plasma proteins in the cauda epididymidis, expressed in $\mathrm{g} / 100 \mathrm{ml}$, was approximately the same as in whole semen and in the semen fractions, except for fraction I (Table 5). The levels of plasma proteins in the cauda epididymidis and in whole semen agrees well with those reported by Mann and Crabo. Between the individual boars there was a significant difference in concentration for the sperm-free fractions VI and VII (Table 5b).

Previous studies on the electrophoretic components of seminal plasma in boars have shown that there are only a few distinct fractions (Boursnell et al. 1962; Bennett 1965), which phenomenon was also observed in the present investigation (Table 5). No comparative study of the electrophoretic pattern in plasma from the cauda epididymidis and the ejaculate was found in the literature. By paper electrophoresis of the contents of the epididymidis, three or four distinct components were observed to migrate towards the cathode. Sedlakova et al. (1968) found a different number of electrophoretic components in the cauda epididymal contents of boars. One of the main components which always occurred in boars was identified as serum albumin by comparison with the electrophoretic pattern of blood serum (Sedlakova et al.). There was, however, no further correspondence between the other electrophoretic components in the cauda epididymal plasma and blood serum. In the present investigation 
none of the electrophoretic components moved like serum albumin neither in the epididymal nor in the seminal plasma. In whole seminal plasma there were usually three visible distinct protein components (Table 5). Bennett describes four protein components in the semen plasma of boars, while Boursnell et al. observed two main peaks in the electrophoretic pattern, as well as traces of more rapidly moving components. Boursnell et al. found that the two main components in semen plasma corresponded to proteins in the vesicular secretion, and they suggest on account of this that the seminal vesicles are the origin of the two main components in the boar. Bennett found that of the most important parts of all the main components in seminal plasma proteins in the boar was sialic acid.

Of the electrophoretic components present in the epididymis, component 1 could not be detected in any of the semen fractions, and component 2 in the sperm-rich fractions only. The concentration of component 1 was probably too low to be detected with the technique used and none of the fractions seemed to have an origin outside the epididymis. The relative amounts of the protein components differed. For example electrophoretic components 4 and 5 dominated the whole seminal plasma picture, while number 3 did so in the cauda epididymal plasma.

The levels of the transaminases GOT and GPT were comparatively low in the seminal plasma, which corresponds with the results of Graham \& Pace (1967), (cf. the values for bulls, Flipse 1960). The enzyme activity of GPT was in contrast to that of GOT higher in the sperm-free fractions than in the spermcontaining fractions (Table 6 ). A direct relationship was found between the number of spermatozoa and units of GOT (Table 6), which phenomenon agrees with the findings of Flipse for bulls. As is evident from Table 6, the amount of GOT was higher in cauda epididymal plasma than in seminal plasma.

The activity of the enzyme alkaline phosphatase was comparatively much higher in the cauda epididymidis than in the ejaculate (Table 6). The concentration in whole seminal plasma corresponds with previous reports (Bell \& Lake 1962). In the semen fractions the amount was largest in the sperm-rich fractions, decreasing gradually to its lowest level in the sperm-free fractions (Table 6 ). There is a clear relationship between the sperm concentration and alkaline phosphatase activity in the seminal plasma. It may be briefly mentioned here that boars 
with a normal concentration of alkaline phosphatase in the seminal plasma (Table 4), produce seminal plasma with a very low concentration following vasectomy. This condition suggests that the origin of alkaline phosphatase is primarily in the testis and epididymis in boars.

\section{REFERENCES}

Bane, A.: Acrosomal abnormality associated with sterility in boar. Proc. IVth Int. Congr. Anim. Reprod., The Hague 1961, 810-817.

Bell, D. J. \& P. E. Lake: A comparison of phosphomonoesterase activities in the seminal plasmas of the domestic cock, turkey tom, boar, bull, buch rabbit and the man. J. Reprod. Fertil. 1962, 3, $363-368$.

Bennett, J. P.: Quantitative comparisons of the proteins of the seminal plasmas of bull, ram, rabbit, and boar by agar gel electrophoresis. J. Reprod. Fertil. 1965, 9, 217-231.

Bonnier, G. \& O. Tedin: Biologisk variansanalys. (Biological analysis of variance). Bonniers, Stockholm 1940.

Boursnell, J. C., P. Johnson \& J. Zamora: An electrophoretic and ultracentrifugal study of boar seminal plasma. Biochim. biophys. Acta (Amst.) 1962, 63, 374-381.

Brun, C.: Klorbestemmelse. En mikrometode. (Determination of chloride. A microchemical method). Nord. Med. 1949, 42, 1774-1776.

Crabo, B.: Studies on the composition of epididymal content in bulls and boars. Acta vet. scand. 1965, 6, suppl. 5.

Drevius, L. O. \& H. Eriksson: Osmotic swelling of mammalian spermatozoa. Exp. Cell. Res. 1966, 42, 136-156.

Einarsson, S.: Unpublished observations, 1969.

Flipse, R. J.: Metabolism of bovine semen. IX. Glutamic-oxaloacetic and glutamic-pyruvic transaminase activities. J. Dairy Sci. 1960, 43, 773-776.

Gledhill, B. L.: Studies on the DNA content, dry mass and optical area of bull spermatozoal heads during epididymal maturation. Acta vet. scand. $1966,7,131-142$.

Glover, T. \& T. Mann: On the composition of boar semen. J. agric. Sci. 1954, 44, 355-360.

Graham, E. F. \& M. M. Pace: Some biochemical changes in spermatozoa due to freezing. Cryobiology 1967, 4, 75-84.

King, E. \& R. Armstrong: A convenient method for determining serum and bile phosphatase activity. Canad. med. Ass. J. 1934, 31, $376-381$.

Lagerlöf, N. \& H. Carlquist: The semen of the Yorkshire breed between the ages of five and nine months. Proc. IVth Int. Congr. Anim. Reprod., The Hague 1961, 818-821.

Lasley, J. F. \& R. Bogart: A comparative study of epididymal and ejaculated spermatozoa of the boar. J. Animal Sci. 1944, 3, 360 370 . 
Lindahl, P. E. \& L. O. Thunqvist: Specific gravity of epididymal and ejaculated bull spermatozoa and of their parts. Experientia (Basel) 1965, 21, 94-95.

Mann, T.: The Biochemistry of Semen and of the Male Reproductive Tract. Methuen, London 1964.

McKenzie, F. F., J. C. Miller \& L. C. Bauguess: The reproductive organs and semen of the boar. Res. Bull. Mo. agric. exp. Sta. 1938, no. 279.

Nesmeianova, T. N.: The potassium, sodium and calcium content in the sperm and secretions of the sexual glands of the boar. Usp. zootekh. Nauk. 1936, 2, 252-266.

Pickett, B. W., R. J. Komarek, M. R. Gebauer, R. W. Benson \& E. W. Gibson: Lipid and dry weight of ejaculated, epididymal and post-castrate semen from boars. J. Animal Sci. 1967, 26, 792798.

Reitman, S. \& S. Frankel: A colorimetric method for the determination of serum glutamic oxaloacetic and glutamic pyruvic transaminases. Amer. J. clin. Path. 1957, 28, 56-63.

Rothschild, L. \& H. Barnes: Osmotic pressure of bull semen diluents. Nature (Lond.) 1954, 173, 636-637.

Salisbury, G. W., C. B. Knodt \& R. W. Bratton: The freezing point depression of bull semen and its relation to the diluter problem. J. Animal Sci. 1948, 7, 283-290.

Salisbury, G. W. \& R. G. Cragle: Freezing point depressions and mineral levels of fluids of the ruminant male reproductive tract. Proc. III Int. Congr. Anim. Reprod., Cambridge 1956, 25-28.

Sedlakova, E., J. Dostal \& J. Matousek: Serum albumin in pig epididymis. Comp. Biochem. Physiol. 1968, 26, 143-148.

Taussky, H., E. Skorr \& G. Kurzman: A microcolorimetric method for the determination of inorganic phosphorus. J. biol. Chem. 1953, $202,675-685$.

Valmet, E. \& H. Svensson: Some problems inherent in paper electrophoresis. The LKB paper electrophoresis apparatus. Sci. Tools $1954,1,3-7$.

Weichselbaum, T. E.: An accurate and rapid method for the determination of proteins in small amounts of blood serum and plasma. Amer. J. clin. Path. tech. 1946, 16, suppl., 40-49.

\section{SUMMARY}

A comparative study was carried out on the chemical composition of plasma from the cauda epididymidis, semen fractions, and whole semen of boars. A total of 22 boars were used in this study. The boars, which ranged in age from 8 to 14 months, were of Swedish Landrace and Swedish Yorkshire breed. All boars used presented a normal semen picture. A dummy sow and an artificial vagina were employed for semen collection. The semen was collected as whole semen and as semen fractions in $10 \mathrm{ml}$ volumes. The contents of the cauda epididymidis was removed post mortem. 
The following parameters were investigated: sperm concentration, dry weight of spermatozoa and of seminal plasma, osmotic pressure, sodium, potassium, chloride, inorganic phosphorus, calcium, magnesium, total protein, GOT, GPT, and alkaline phosphatase in seminal plasma. Paper electrophoresis was carried out on seminal plasma. The results of the analysis are summarized in Tables $1-6$.

The sperm concentration was approximately $3.2 \mathrm{mill} . / \mathrm{mm}^{3}$ in the cauda epididymidis, $1 \mathrm{mill} . / \mathrm{mm}^{3}$ in the sperm-richest fraction (II) and $0.25 \mathrm{mill} . / \mathrm{mm}^{3}$ in whole semen. The dry weight (expressed in per cent dry matter) of spermatozoa was highest in the cauda epididymidis $(25.47 \%)$, showing a tendency to decreasing in semen fractions I-IV and was lowest in whole semen $(\mathbf{1 5 . 2 9} \%)$. The per cent dry weight in plasma was higher in the cauda epididymidis $(4.56 \%)$ than in semen fraction I $(2.20 \%)$. In semen fractions I-IV the per cent dry weight rose from $2.20 \%$ to $4.51 \%$ and reached the level of approximately $3.80 \%$ in the sperm-free fractions V-VII. The osmotic pressure was significantly higher in the cauda epididymal plasma than in the whole seminal plasma or the seminal plasma fractions. The same phenomenon was observed in a boar where the cauda epididymal content was collected in vivo from a patent established fistula. There appears to be a connection between the per cent dry weight of spermatozoa and the osmotic pressure, which means that the per cent dry weight of the cauda epididymal spermatozoa decreases when mixed with the accessory gland secretions, which have a lower osmotic pressure. The fall in per cent dry weights is thought to be caused by an intake of water.

The amount of sodium, chloride and magnesium was higher in ejaculated seminal plasma than in cauda epididymal plasma. The reverse was true for inorganic phosphorus and potassium. Moreover the sperm-free fractions contained more sodium, chlorides and magnesium than the sperm-containing fractions, while the concentration of potassium and inorganic phosphorus was comparatively higher in the sperm-containing fractions. A connection is apparent between sperm concentration and the potassium, inorganic phosphorus and magnesium levels. Statistical analysis of the values of chloride and magnesium revealed significant differences between individual boars for most of the semen fractions.

The concentration of plasma proteins in the cauda epididymidis was approximately the same as in whole semen and in the semen fractions except for fraction $I$, which contained a relatively low concentration. As regards total protein there were significant differences between individual boars in most of the semen fractions as well.

The paper electrophoretic pattern of epididymal plasma was different from that of semen plasma. Thus there were three or four distinct components in the cauda epididymidis numbered 1, 2, 3, and 4 , and three distinct components in whole seminal plasma numbered 3,4 , and 5, while the sperm-richest semen fractions contained four components $(2,3,4$, and 5$)$ and the others three components, namely 3,4 , and 5 . 
The level of GOT was high in the cauda epididymal contents (99.1 i. u./ml) compared with that for whole seminal plasma (11.1 i. $u . / \mathrm{ml}$ ). In semen fractions there was a clear positive correlation between the level of GOT and the sperm concentration. The GPT concentration was as a whole low and, in contrast to GOT, somewhat higher in the sperm-free fractions than in the sperm-containing fractions. The concentration of alkaline phosphatase was very high in cauda epididymal plasma $(31,463 \mathrm{i} . \mathrm{u} . / \mathrm{ml})$ as well as in the sperm-rich fractions (e. g. 7,096 i. u./ml in fraction II). Preliminary investigation has moreover revealed a very low alkaline phosphatase concentration in seminal plasma of vasectomized boars, which condition suggests that the main origin for alkaline phosphatase in boars is the testis and epididymis.

\section{SAMMANFATTNING}

En jämförande studie över kemiska sammansättningen av plasma från bitestikelsvans, ejakulatfraktioner och helejakulat hos galt.

En jämförande studie har utförts över kemiska sammansättningen av plasma från bitestikelsvans, ejakulatfraktioner och helejakulat hos galt. Materialet har tagits från totalt 22 galtar av svensk lantras och svensk yorkshireras med en ålder varierande mellan 8 och 14 månader. Samtliga galtar uppvisade en normal spermabild. Spermasamlingen skedde på suggfantom i artificiell vagina. Sperman uppsamlades dels som helejakulat dels i fraktioner om vardera $10 \mathrm{ml}$. Bitestikelsvansinnehållet uttogs post mortem.

Följande parametrar undersöktes. Spermiekoncentration, torrviktsprocent i spermier och spermaplasma, osmotiskt tryck, natrium, kalium, klorid, oorganiskt fosfor, kalciım, magnesium, total protein, GOT, GPT, samt alkaliskt fosfatas i spermaplasma. Dessutom utfördes papperselektroforetisk undersökning av spermaplasman. Analysresultaten återfinns i tabellerna $1-6$.

Spermiekoncentrationen låg på 3,2 millioner $/ \mathrm{mm}^{3}$ i bitestikelsvansen, c:a $1 \mathrm{million} / \mathrm{mm}^{3}$ i den spermierikaste fraktionen (II) och 0,23 millioner $/ \mathrm{mm}^{3}$ i helejakulat. Torrvikten (uttryckt i \% torrsubstans) i spermier var högst i bitestikelsvansen $(25,47 \%)$, visade en fallande tendens genom de spermieinnehållande fraktionerna (I-IV) samt var lägst $\mathrm{i}$ helejakulat $(\mathbf{1 5 , 2 9} \%)$. Plasmans torrviktsprocent var högre $\mathrm{i}$ bitestikelsvansen $(4,56 \%)$ jämfört med ejakulatfraktion I $(2,20 \%)$. I de spermieinnehållande fraktionerna (I-IV) steg plasmans torrviktsprocent från $2,20 \%$ till 4,51 \% medan den konstant låg på c:a 3,80\% i de spermiefria fraktionerna (V-VIII). Osmotiska trycket var högt, signifikant högre $i$ bitestikelsvansplasman än i plasma från helejakulat och ejakulatfraktioner. Samma förhållande har konstaterats in vivo på galt med anlagd permanent sädessträngsfistel. Ett samband synes föreligga mellan spermiernas torrviktsprocent och det osmotiska trycket såtillvida, att torrviktsprocenten i spermierna från bitestikelsvansen sjunker då de förs över i accessoriska könskörtlarnas sekret med lägre osmotiskt tryck. Denna minskning av 
torrviktsprocenten tros bero på ett vätskeupptagande av spermierna vid ejakulationen.

Jämförande studier över elektrolythalten i plasman visade att koncentrationen av natrium, klorid och magnesium var högre i ejakulat än i bitestikelsvans i motsats till förhållandet för kalium och oorganiskt fosfor. Likaså innehöll de spermiefria fraktionerna högre halt av natrium, klorid och magnesium än de spermieinnehållande medan halten av kalium och oorganiskt fosfor var jämförelsevis högre i de spermieinnehållande fraktionerna. Ett samband synes föreligga mellan spermiekoncentration och halten kalium, oorganiskt fosfor samt magnesium. Signifikant skillnad återfanns mellan enskilda galtar för klorid- och magnesiumhalten i flertalet ejakulatfraktioner.

Skillnaden i plasmans totalproteinhalt var obetydlig mellan bitestikelsvans, helejakulat och ejakulatfraktioner med undantag av fraktion I, som innehöll en jämförelsevis låg halt. Även för totalproteinhalten återfanns en signifikant skillnad mellan enskilda galtar i flertalet ejakulatfraktioner.

Papperselektroforetiska mönstret var olika för bitestikelsvans och ejakulat. Sålunda visade bitestikelsvansen 3 eller 4 distinkta band, benämnda 1, 2, 3 och 4; helejakulatplasma 3 distinkta band, benämnda 3,4 och 5, medan de spermierikaste ejakulatfraktionerna innehöll 4 komponenter $(2,3,4$ och 5$)$ och de övriga 3 , nämligen 3,4 och 5 . GOT-halten var jämförelsevis hög i bitestikelsvansplasma $(99,1$ i. e.) jämfört med helejakulatplasma $(11,1$ i. e.). I ejakulatfraktionerna förelåg en tydlig positiv korrelation mellan GOT-halt och spermiekoncentration. GPT-halten var genomgående låg och var i motsats till GOT något högre $i$ de spermiefria ejakulatfraktionerna jämfört med de spermieinnehållande. Enzymkoncentrationen av alkaliskt fosfatas var mycket hög i plasma från bitestikelsvans $(31.463$ i. e. $/ \mathrm{ml})$, vilket också var fallet $i$ de spermierika fraktionerna (ex. 7.096 i. e./ml i fraktion II). Preliminära undersökningar har dessutom visat att koncentrationen av alkaliskt fosfatas är mycket låg i ejakulatplasma från vasektomerade galtar, varför enzymet huvudsakligen tycks komma från testikel-bitestikel hos galt.

(Received July 14, 1969). 